\title{
In vitro Efficacy and Population Dynamics of Fungal and Bacterial Antagonists against Chilli Damping Off
}

\author{
Misba Majeed $^{1 *}$, G. Hassan Mir ${ }^{1}$, Fayaz A. Mohuiddin ${ }^{1}$, Mudasir Hassan ${ }^{1}$, \\ Shazia Paswal ${ }^{2}$ and Saima Farooq ${ }^{2}$ \\ ${ }^{1}$ Division of Plant Pathology, Sher-e-Kashmir University of Agricultural Sciences and \\ Technology of Kashmir, 190025, India \\ ${ }^{2}$ Division of Plant Pathology, Sher-e-Kashmir University of Agricultural Sciences and \\ Technology of Jammu, 180009, India \\ *Corresponding author
}

\section{A B S T R A C T}

\begin{tabular}{|l|}
\hline K e y w o r d s \\
$\begin{array}{l}\text { Antagonists, Bacillus subtilis, } \\
\text { Biocontrol agents, } \\
\text { Pseudomonas flourescens, } \\
\text { Pythium aphanidermatum, } \\
\text { Rhizospheric population, } \\
\text { Trichoderma harzianum, } \\
\text { Trichoderma viride }\end{array}$ \\
\hline Article Info \\
\hline $\begin{array}{l}\text { Accepted: } \\
\text { 23 March } 2018 \\
\text { Available Online: } \\
\text { 10 April } 2018\end{array}$ \\
\hline
\end{tabular}

\section{Introduction}

Chilli (Capsicum annuum L) is an important vegetable and crop grown all over the world. The crop is attacked by many soil borne pathogens. Among them, Pythium aphanidermatum causing damping off disease in chilli leads to damping off in seedlings and crown and root rot in older plants. The genus Pythium is a complex genus containing over 200described species that occupy a variety of terrestrial and aquatic ecological habitats (Dick, 2001). With the increased concern about pesticide hazards and environmental degradation, innovative method of disease control like bio-control is under investigations. The antagonists such as Trichoderma (Rajan et al., 2002), Pseudomonas fluorescens (Elad and Chet, 1987) and native isolates have been successfully used for the biocontrol of damping-off disease. In recent years, attempts are made to use a consortium (association of two) of biocontrol agents to get persistent control of plant pathogens (Chaube and Sharma, 2002). Keeping this in view and the growing importance of biological control 
agents, the present study was carried out to evaluate the biocontrol efficiency of $T$. viride, T. harzianum, B. subtilis and P. fluorescens against $P$. aphanidermatum and to study their population dynamics in pot culture experiment.

\section{Materials and Methods}

The present investigations on the "In vitro efficacy and Population Dynamics of Fungal and Bacterial antagonists against Chilli Damping Off" were conducted at Fruit and Floriculture Laboratory in the Division of Plant Pathology, Sher-e-Kashmir University of Agricultural Sciences and Technology, Shalimar Campus.

\section{Isolation, identification and purification of pathogen}

The chilli seedlings bearing the characteristic symptoms of disease were collected from different chilli nurseries and brought to the laboratory for isolation of the pathogen. The infected plant parts were cut into small bits and surface sterilized with 0.1 per cent mercuric chloride for about 30 seconds followed by three consecutive rinses in sterilized distilled water and blotter dried. The bits were then aseptically transferred to potato dextrose agar (PDA) medium in petri plates and incubated at $24 \pm 1^{\circ} \mathrm{C}$ for 7 days. After seven days of incubation fungal growth began to appear on the plates and tips of the growing mycelium were cut off and transferred to PDA slants. The cultures thus obtained were purified by single spore technique (Tuite, 1969). The pure culture was maintained on PDA and preserved by storing culture tubes at $4^{\circ} \mathrm{C}$ in a refrigerator. The culture was revived periodically at an interval of 3 months. Morphological characteristics of the causal organism were studied both on host and in pure culture for its identification. Shape, colour, size and septation of mycelium, conidiophore and conidia were studied and compared with the standard description given by Plaats-Niterink (1981) for the identification of pathogen.

\section{Maintenance of bio-control agents}

Bio-control agents viz., Trichoderma viride, Trichoderma harzianum, Pseudomonas fluorescens and Bacillus subtilis were obtained from the Division of Plant Pathology, SKUAST-K, maintained on PDA, King's B and Nutrient Agar medium, and periodically sub-cultured at monthly intervals. Mass multiplication was done on Potato Dextrose broth, Nutrient broth and King's B broth in Erlenmeyer flasks.

\section{Effect of volatile metabolites of antagonists}

Production of volatile metabolites by $T$. viride, T. harzianum, P. fluorescens, and Bacillus subtilis isolates were evaluated by Inverted plate technique (Dennis and Webster, 1971). The Petri plates having test pathogens were inverted on same sized Petri plates (mouth to mouth) having actively growing seven days old culture of bio-control agents. These Petri plates were sealed with Para film under aseptic conditions. Petri plates without biocontrol agents served as control. Each treatment was replicated thrice. Colony size in each treatment was recorded and percent inhibition calculated by using the formula as proposed by Vincent (1947).

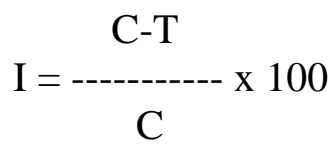

Where,

$\mathrm{I}=$ Inhibition of mycelial growth $(\%)$

$\mathrm{C}=$ Growth of pathogen in control $(\mathrm{mm})$

$\mathrm{T}=$ Growth of pathogen in treatment $(\mathrm{mm})$ 
To study the rhizosphere population of inoculated antagonists

To assess the population of inoculated antagonists (bio-control agents) in the soil at 30 and 60 days after inoculation, a pot culture experiment was conducted in green house conditions. 42 pots were filled with steamsterilized soil amended with compost (3:1) for providing nutrition to pathogen. Inoculum disc $(5 \mathrm{~mm})$ of the pathogen was slotted with cork borer and transferred to sterile soil in pots. For incubation and stability of pathogen, these pots were covered with plastic sheet so to create the humidity for 4 days. Fifteen plants were transplanted in each pot and the antagonists were added into the pots after a few days with different spore loads. At 30 and 60 days after inoculation of antagonists, five plants were randomly selected and uprooted. The loosely adhering soil particles were removed by gentle tapping and $1 \mathrm{~g}$ of soil sample was taken and suspended in $9 \mathrm{ml}$ sterilized water. The dilutions were made as $10^{-1}, 10^{-2}, 10^{-3}, 10^{-4}$ and $10^{-5}$ respectively. The diluted samples were inoculated on PDA and NA and incubated at $30^{\circ} \mathrm{C}$ and $37^{\circ} \mathrm{C}$ for the 7 days to procure bacterial and fungal colonies (Aneja, 1993). Thusa total population of bacterial and fungal bio-control isolates were calculated in cfu.

\section{Results and Discussion}

\section{Effect of volatile metabolites of antagonists}

Assay for effect of volatile metabolites produced by antagonists against $P$. aphanidermatum revealed that $T$. viride and $T$. harzianum both produced toxic volatile metabolites having significant effect in reducing the radial growth of the test pathogen and forming a prominent zone of inhibition (Table 1). In case of Pseudomonas fluorescens and Bacillus subtilis no zone of inhibition was formed with lesser growth inhibition of test pathogen. The maximum inhibition was recorded in T. harzianum (92.32\%) followed by $T$. viride $(90.22 \%)$. The minimum inhibition growth was noted as 59.84 per cent over control for B. subtilis. The results are having conformity with those of Amin et al., (2010) and Jeyaseelan et al., (2012). Jeyaseelan et al., (2012) reported that the volatile metabolites of $T$. harzianum and $T$. viride showed significant growth inhibition against $P$. aphanidermatum at 24 hours incubation. The inhibition produced by the $T$. harzianum was significantly higher than that produced by $T$. viride. However, there was no significant difference between the radial growths of $P$. aphanidermatum present in test and control plates at 48 hours incubation. Among bacterial antagonists, they showed lesser inhibition with no clear zone of inhibition.

Species of Trichoderma have been demonstratedin vitro to act against fungal plant pathogens by producing diffusible volatile antibiotics. Claydon et al., (1987) reported antifungal properties of volatile compounds (Alkyl pyrones) produced by $T$. harzianum. Similarly Rathore et al., (1992) reported volatile activity of $T$. viride against $F$. solani which vacuolated most hyphae of pathogen and that hyphae was comparatively thin as compared to control. Jeyaseelan et al., (2012) reported that five Bacillus spp. among nine failed to show any inhibition zone. This may be due to the lack of ability to produce antimicrobial compounds, which are inhibitive to $P$. aphanidermatum or may be inadequate production of antimicrobial compounds.

Effect on the number of rhizospheric population of biocontrol agents

The plant root colonization ability of four biocontrol agents for different treatments on chilli at different time point after application into soil was noted. 
Table.1 Effect of volatile metabolites produced by different bio-control agents against mycelial growth of Pythium aphanidermatum

\begin{tabular}{|c|c|c|}
\hline Treatments & $\begin{array}{l}\text { Average radial } \\
\text { growth (mm) }\end{array}$ & Radial growth inhibition (\%) \\
\hline Trichoderma viride & 8.80 & $90.22^{\mathrm{b}}(71.79)$ \\
\hline T. harzianum & 6.91 & $92.32^{\mathrm{a}}(73.95)$ \\
\hline Pseudomonas fluorescens & 35.54 & $60.51^{\mathrm{c}}(51.07)$ \\
\hline Bacillus subtilis & 36.14 & $59.84^{\mathrm{c}}(50.68)$ \\
\hline Control & 90.00 & - \\
\hline S.E(d) & & 0.50 \\
\hline C.D $(p \leq 0.05)$ & & 1.0623 \\
\hline
\end{tabular}

Values in parenthesis are arc sine transformed

Table. 2 Population dynamics of bio-control agents after 30 and 60 days of inoculation in rhizosphere

\begin{tabular}{|c|c|c|c|}
\hline $\begin{array}{r}\text { Days } \\
\text { Treatments }\end{array}$ & Treatments & $\begin{array}{c}* 30 \text { days (cfux } 10^{5} / g \\
\text { soil) }\end{array}$ & $\begin{array}{c}\text { *60 days (cfux } 10^{5} / g \\
\text { soil) }\end{array}$ \\
\hline $\mathbf{T}_{1}$ & Trichoderma viride & 2.33 & 2.67 \\
\hline $\mathbf{T}_{2}$ & T. harzianum & 2.33 & 3.00 \\
\hline $\mathbf{T}_{3}$ & Pseudomonas fluorescens & 2.33 & 2.67 \\
\hline $\mathbf{T}_{4}$ & Bacillus subtilis & 2.33 & 2.67 \\
\hline $\mathbf{T}_{5}$ & T. viride $+T$. harzianum & $2.83(2.67+3.00)$ & $3.50(3.33+3.67)$ \\
\hline$\overline{T_{6}}$ & $T$. viride $+P$. fluorescens & $2.50(3.00+2.00)$ & $3.33(3.67+3.00)$ \\
\hline $\mathbf{T}_{7}$ & T. viride + B. subtilis. & $2.50(3.00+2.00)$ & $3.33(3.67+3.00)$ \\
\hline $\mathbf{T}_{8}$ & $\begin{array}{l}\text { T. harzianum }+P \text {. } \\
\text { fluorescens }\end{array}$ & $2.67(3.00+2.33)$ & $3.50(4.00+3.00)$ \\
\hline $\mathbf{T}_{9}$ & T. harzianum + B. subtilis. & $2.50(3.00+2.00)$ & $3.50(4.00+3.00)$ \\
\hline $\mathbf{T}_{10}$ & P. fluorescens $+B$. subtilis. & $2.33(2.33+2.33)$ & $3.33(3.67+3.00)$ \\
\hline $\mathbf{T}_{11}$ & $\begin{array}{l}\text { Trichoderma viride }+T . \\
\text { harzianum }+ \text { Pseudomonas } \\
\text { fluorescens }+ \text { Bacillus subtilis }\end{array}$ & $\begin{array}{c}3.25 \\
(4.00+3.67+2.67+2.67)\end{array}$ & $\begin{array}{c}4.83 \\
(5.67+5.33+4.33+4.00)\end{array}$ \\
\hline$T_{12}$ & Ridomil MZ & 0.00 & 0.00 \\
\hline $\mathbf{T}_{13}$ & Check (sick plot) & 0.00 & 0.00 \\
\hline \multirow[t]{4}{*}{$\mathbf{T}_{14}$} & Sterilized soil & 0.00 & 0.00 \\
\hline & Mean & 1.99 & 2.62 \\
\hline & C.D $(p \leq 0.05)$ & & \\
\hline & & $\begin{array}{l}\text { Treatment }(\mathrm{T}) \\
\text { Days (D) } \\
\text { T x D }\end{array}$ & $\begin{array}{l}0.3838 \\
0.1451 \\
0.5428\end{array}$ \\
\hline
\end{tabular}

Values in parenthesis are individual population of biocontrol agents 
The results in Table 2 indicated that the highest population of biocontrol agents was noted as $3.25 \times 10^{5} / \mathrm{g}$ soil and $4.83 \times 10^{5} / \mathrm{g}$ soil in Trichoderma viride $+T$. harzianum + Pseudomonas fluorescence + Bacillus subtilis $\left(\mathrm{T}_{11}\right)$ at 30 and 60 days of inoculation. Thus results in Table 2 indicate that the biocontrol agents showed synergistic effect with each other without inhibiting the growth of others.

Combined application of Trichoderma viride $+T$. harzianum + Pseudomonas fluorescens + Bacillus subtilis $\left(\mathrm{T}_{11}\right)$ exhibited maximum rhizospheric population of bio-control agents (antagonists) in the soil as 3.25 and 4.83 cfux $10 \%$ g soil at 30 and 60 days after inoculation.

The population of fungal antagonists were maximum than bacterial antagonists.In the event of antagonism it is essential that growing together of antagonistic and target organisms near the vicinity or interact each organism at least by means of antagonist compounds produced by the biocontrol agent with the target organism and population of the biocontrol agent should be maintained at threshold level in the rhizosphere (Raaijmakers et al., 1995).

The results were in conformity with Abheysinghe (2009). He also observed less bacterial population compared to fungal antagonist and was of the opinion that most probably seed bacterization with physiologically active bacteria takes advantage of vigorous root colonization hat does not happen when applied in soil.

Also soil application of bacteria could have disappeared in rhizosphere via percolation or exclusion of bacterial antagonists for microbial competition thereby deprived from biocontrol ability. Weller (1988) also reported that the population of biocontrol agent in the rhizosphere and the biocontrol activity seems to be directly correlated.

\section{References}

Abeysinghe, S. 2009. Effect of combined use of Bacillus subtilis CA32 and Trichoderma harzianum RU01 on biological control of Rhizoctonia solani on Solanum melongena and Capsicum annum. Plant Pathology Journal 8: 916.

Amin, F., Razdan, V.K., Mohiddin, F.A., Bhat, K.A. and Sheikh, P.A. 2010a. Effect of volatile metabolites of Trichoderma species against seven fungal plant pathogens in vitro. Journal of Phytology 2: 34-37

Aneja, K.R. 1993. Experiments in microbiology, plant pathology and tissue culture. New Delhi Vishwa Prakashan 35: 142-197.

Chaube, H. S. and Sharma, J. 2002. Integration and interaction of solarization and fungal and bacterial bioagents on disease incidence and plant growth response of some horticultural crops. Plant Disease Research, 17: 201.

Claydon, N., Allan, M., Hanson, J.R. and Avent, A.J. 1987. Antifungal alkyl pyrenes of Trichoderma harzianum. Transactions of the British Mycological Society 88: 503-513

Dennis, C. and Webster, J. 1971. Antagonistic Properties of Species Groups of Trichoderma. I. Production of Nonvolatile Antibiotics. Transactions of the British Mycological Society 57: 25-39.

Dick, M. W. 2001. The peronosporomyletes In: the mycota VII part A. Systematics Evolution (eds. D. j. McLaughlin, E.G. McLaughlin and P.A. Lemke), Springer Verlag, Berlin. Pp. 39-72.

Elad, Y. and Chet, I. 1987. Possible role of competition for nutrient in biocontrol of Pythium damping-off by bacteria. Phytopathology, 77: 190 -195. 
Jeyaseelan, E.C., Tharmila, S. and Niranjan, K. 2012. Antagonistic activity of Trichoderma spp. and Bacillus spp. against Pythium aphanidermatum isolated from tomato damping off. Archives of Applied Science Research, 4:1623-1627.

Plaats-Niterink, A.J.V. 1981. Monograph of the genus Pythium. Studies in Mycology, 21: 1-242.

Raaijmakers, J.M., Van Oorschot, M.M.P., Van der Sluis, I., Schippers, B. and Bakker, P.A.H.M. 1995. Dose response relationship in biological control of Fusarium wilt of radish by Pseudomonas sp. Phytopathology, 85: 1075-1081.

Rajan, P.P., Sharma, Y.R. and Anandaraj, M. 2002. Management of foot rot disease of black pepper with Trichoderma spp. Indian phytopathology, 55: $34-38$.

Rathore, V.R.S., Mathur, K., Hodha, B.C. and Mathur, K. 1992. Activity of volatile and non- volatile substances produced by Trichoderma viride on ginger rhizome rot pathogens. Indian Phytopathology, 45: 253-254

Tuite, J. 1969. Plant Pathological Methods; Fungi and Bacteria. Burgers Publishing Co., Minneapolis, USA, pp. 1-238.

Vincent, J.M. 1947. Distortion of fungal hypha in the presence of some inhibitors. Nature, 159: 850.

Weller, D. M. 1998. Biological control of soil borne pathogens in the rhizosphere with bacteria. Annual Review of Phytopathology, 26: 379-407

\section{How to cite this article:}

Misba Majeed, G. Hassan Mir, Fayaz A. Mohuiddin, Mudasir Hassan, Shazia Paswal and Saima Farooq. 2018. In vitro Efficacy and Population Dynamics of Fungal and Bacterial Antagonists against Chilli Damping Off. Int.J.Curr.Microbiol.App.Sci. 7(04): 3025-3030. doi: https://doi.org/10.20546/ijcmas.2018.704.342 